\title{
Research's "Quality" in Industry 4.0. The Definition of a Human Measure for Evaluating of Research in Education
}

\author{
Emanuela Guarcello* \\ Philosophy and Educational Sciences, Department University of Turin, Italy \\ *Corresponding Author: Emanuela Guarcello, Philosophy and Educational Sciences, Department \\ University of Turin, Italy
}

\begin{abstract}
Research, as a systematic study of what is part of human existence, is influenced by and influences the world it studies, seeks to know and transform. This reciprocal relationship is marked today by a profound digital revolution: The Fourth Industrial Revolution -Industry 4.0. This digital revolution in the world of production is marked by a deep redefinition of work which has entailed a deep redefinition of identity not only of the worker but above all of the person immersed in a society transformed by digital. This same redefinition also involves research in science education, which must increasingly be subjected to analysis, understanding and proposal of practices concerning research issues that present, both enormous potential and complex risks or even dangers for the protection of the dignity of humanity and, indeed, for its survival. In fact, we think of Big Data and the possibility of predicting behaviours or offering pre-configured indications for medical treatments and for making health choices for patients. We still think, for example, of robotics as an implementation of the work of professionals at school or in health care or as a replacement of home care for people with chronic or degenerative health problems
\end{abstract}

Against this background, the essay asks: on the basis of which criteria should the quality of research in science education be assessed? Can the quality of the researcher be defined in industry 4.0 only in terms of experimental reliability and validity, or must it also be defined in terms of "human" value of research questions, processes and findings?

Key terms: industry 4.0, research, quality, evaluation.

\section{A Society Transformed by Digital}

Nowadays analysis of educational research quality cannot be separated from a reflection on the characteristics of socio-economic world within which research is set. Indeed, starting from the working environment, human existence has been shaken and subverted by technological changes which were so disruptive to mark a break with the past and so deep that they have revolutionized the pre-existent paradigms

Just for their disruptiveness and depth, these changes have led to the start of a revolution which has taken the name of Fourth Industrial Revolution -Industry 4.0- and which is defined through the paradigm of flexibility and innovation connected, in particular, to the digitalization of operative activities and to the remote control of production and the flow of material (World Economic Forum 2016). This digital revolution in the world of production is marked by a deep redefinition of work (McAfee, Brynjolfsson 2014, 2017; Seghezzi 2018) which has entailed a deep redefinition of identity (Bauman 1998, 2005) not only of the worker but above all of the person immersed in a society transformed by digital.

Among the main characteristics of this society transformed by digital, one in particular has stimulated and influenced redefinition of human identity: the digital ubiquity (Iansiti, Makhani 2014). Digital ubiquity concept expresses the digital capacity to create and promote endless informative flows «generated by interactions which develop among the thousand output processes existing in a common global space» (Cipriani, Gramolati, Mari 2018, p. 221, traduzione nostra). It is a space which implies for the person both the risk and the potentiality of moving within an interactive context, changeable and constantly connected without time and space limits. 
«The new normality» peculiar of this interactive context «finds a good synthesis in the Vuca acronym» (Garbellano 2019, p. 19), formed by the words Volatility, Uncertainty, Complexity and Ambiguity. V.U.C.A. expresses and synthesizes the particular conditions which influence objects, processes and practices of the world in which man lives ${ }^{1}$. They are conditions which express themselves through speed and unrest (Volatility), risk and unpredictability (Uncertainty), uncertainty and interconnection (Complexity), contradictoriness and vagueness (Ambiguity).

Just because the person is immersed in this society transformed by digital and in its V.U.C.A. conditions, he/she has to work at a constant redefinition not only of his/her identity but also of his/her evaluating capacity. Since Industry 4.0 is a perennially accessible space which offers digitalized resources that are complex, unlimited and undefined, fast and multiple, the person has to carry out a constant evaluation to select time by time the fittest choices, to manage these choices thanks to methodologies and processes that cope with V.U.C.A. conditions, to orient choices, methodologies and processes towards a sense direction that can protect and promote human dignity.

\section{RESEARCH WITHIN DIGITAL SOCIETY}

If society and man are immersed and influenced by V.U.C.A. conditions, at the same time also educational research -which nowadays is designed, experimented and realized by that "man of Industry 4.0"- is immersed in this context transformed by digital. Against this background, the essay asks: on the basis of which criteria should the quality of research in science education be assessed? Can the quality of the researcher be defined in industry 4.0 only in terms of experimental reliability and validity, or must it also be defined in terms of "human" value of research questions, processes and findings?

In order to be able to work on an initial definition of these questions, consideration should be given to the fact that educational research is immersed in digital at least under three different aspects. Firstly, it is a research which answers to research questions that arise from this context transformed by digital. Secondly, it is a research led by researchers who are "perturbed" (Zeilinger 2003) by this context transformed by digital. Thirdly, it is a research which must be able to assess whether its object, method and "product" safeguards and promotes a significant and valuable life.

Firstly, the educational research is immersed in digital because it answers to research questions that arise from this context transformed by digital. We must not think only of the topics related to digital media, their conception, design, implementation, analysis and usability. Other digital issues such as artificial intelligence, genetics, robotics, data collection and analysis should also be considered. In fact, we think of artificial intelligence and the possibility that opens up to man to overcome his limits, to exceed his own capacity to think and plan a course of action. We also think of the bio-genetics and the power that it gives man to vary his physical limits, having not only aids that repair damage or physiological problems (disability or amputations), but also of "qualities" that amplify one's body.

«My enhanced limb, my prosthetic limbs, allow me to go beyond the limits of my body. But what orders will I give to my limb? In which ethical register do I inscribe my power of action? Can my enhanced hand effortlessly kill?» (Abbate 2019, p. 83, our translation).

We still think of Big Data and the possibility of predicting behaviours or offering pre-configured directions to professionals for medical treatments and patients for their health choices, but there is also the risk of absolving the responsibility of both care operators and patients. Finally, while being aware of the many other possible examples, we think of robotics used in the implementation of the work of professionals in school and health care or in the replacement of home care for people with

\footnotetext{
${ }^{1}$ V.U.C.A. «was coined in the 1990s by the US army as it was gearing for the possible asymmetric wars of the next century» (Gupta, Gupta, 2018, p. 90). About its origin, the acronym sees in "Leaders: Strategies for Taking Charge" (Bennis, Nanus, 1985) and in "Training and Educating Army Officers for the 21st Century: Implications for the United States Military Academy" (Whiteman, 1998) two of its most important references. Bill (2017) has recently proposed a revision "2.0" of the acronym, intact in its form but renewed in its substance of concepts which makes it up: Vision, Understanding, Courage, Adaptability (V.U.C.A. 2.0).
} 
chronic or degenerative health problems. The social, health and educational applications of robotics are myriad and are only partially explored on a large scale: robotic surgeons for emergency operations in small peripheral hospitals, robotics at school, at home, in offices, in hotels or means of transport. The application of robotics to human life if on the one hand offers very interesting resources of aid and support, on the other hand it presents many problems: How would health care look if anthropomorphic robots replaced hospital nursing staff? What implications could arise as result of the daily interaction between a robot and an elderly person based on the simulation of an emotional interest by the "machine" and its availability to any request? In what direction could relations between people move? Would men be able to govern digital in order to make their lives more human, or would they be overwhelmed, dehumanized, and then digitalized? Secondly, educational research is immersed in digital not only with respect to these research questions, but also the researcher. Indeed, the researcher is not neutral to the context within which he or she operates. He or she is also a researcher who will be increasingly "transformed by digital":

«Millennials will soon represent the largest proportion of the workforce of exceeding half in 2020 . [...] According to the report by Cegos Millennials Insight 2017 survey trends, millennials have the following characteristics: They are more familiar with the concept of crisis and instability, They have new attitudes towards work and new modes of communication, They have a greater propensity to mobility, also international, and they do not see a clear separation between their private and working lives» (Alessandrini 2018, pp. 40, 42, our translation).

The digital researcher, while presenting an identity which is increasingly compatible with digital, is also called to the task of perfecting those skills which are necessary, for example, critical thinking, creativity, sound judgment, all of which are considered necessary in order to be competitive and above all, we believe, in order to be able to orient oneself within a digital space of unlimited, powerful and upgradeable resources.

«The worker is asked to continually explore the unknown, in the awareness that the objectives can be achieved with diversified paths and where the solutions devised for the action are not necessarily univocal, but emerge from the interaction with others [...] new heuristics of complexity. The heuristic dimension of competent action is thus translated into a multilevel digital process (spatial and temporal) that finds its leverage point in the evaluation and continuous verification of the worker between a set of predetermined parameters and detected during the interaction, between the rhythms and the changing contingencies of the real world. This process generates [...] a new concept of flexibility $[\ldots]$ centred on the analytical, choice and action capabilities that take place in a space $[\ldots]$ that reconfigures unceasingly» (Costa 2017, p. 222, our translation).

Thirdly, precisely because it is immersed in digital, educational research, while placing the researcher in a space of potentiality, calls him/her to a task of responsibility: evaluating research questions, processes and findings to Judge, each time, if they can promote a meaningful life for man in Industry 4.0. The researcher must have the ability to evaluate systematically, firmly and authoritatively the risks and excess of researcher's questions, processes and findings which might make education and persons trans-human (Bostrom 2005, 2008; Marchesini 2009)2.

Consequently, the researcher is recalled to a difficult commitment of responsibility towards educational research in order to orient it not only towards the competitiveness of the result or the functionality of the use, but primarily towards the 'common good" and 'justice'. These are the criteria that must guide the evaluation of research in Industry 4.0, so that it is a quality research.

\section{THE HUMAN MEASUREMENT OF QUALITY EDUCATIONAL RESEARCH}

Precisely because it is immersed in a society transformed by digital, the researcher has to work on a redefinition of its evaluating capacities. In fact, the researcher must be able to evaluate the what of the

\footnotetext{
${ }^{2}$ Transhumanism connects to one of the main critical nodes of Industry 4.0, the unlimited and indiscriminate empowerment of man (enhancement) and expresses a condition «in which the limits of every humanism will be exceeded: old age, illness, cognitive deficiencies, behavioural syndromes» (Abbate 2019, p. 83, our translation; Bostrom 2005, 2008).
} 
research (research questions and methods), the who of research (his/her position towards the research) and the what-for of the research (sense and direction of research findings

Precisely because it is immersed in a society transformed by digital, the researcher cannot also plan for what, who, and what-for at the same level. In fact, as presented in the previous paragraph, digital, for the problematic issues that it raises, requires the research to establish a priority between the different levels of evaluation and this priority must be the what-for of research.

«Today we must be ready to bring new types of metamorphosis back into ethics: robotics, genetic engineering, cloning, biomedical nanotechnology, prosthetics, to remain within the sphere of mutations of the human body. Already at this level, the question we will soon have to ask ourselves is this: How will our capacities be enhanced? [...] Will the human measure remain the same?» (Abbate 2019, p. 82, our translation).

The what for of educational research, or in other words, the direction it must take, is linked precisely to this concept of human measure. It is in fact the maintenance and promotion of this human measure that directs the assessment to the quality of the objects, the questions, the methods, the instruments and the achievements of the research.

In Industry 4.0 the evaluation of the quality of educational research can no longer prioritise the experimental "measurement" of reliability and validity. Just as Industry 4.0 represents a revolutionary transformation of our world, in the same way the evaluation of the quality of research -which that world studies - must meet a Copernican revolution. In Industry 4.0 the measurement of reliability and validity must of course not disappear but it is important that it loses its priority and central position in favour of the measurement of the "human" which research has the ability to preserve or, even better, promote.

What studies can offer a conceptual framework in support of this concept of human "measure" and how is it possible to translate 'operationally" to be able to recognize, measure and evaluate it?

A particularly relevant and significant conceptual framework can be represented by Martha Craven Nussbam's approach to skills. According to this approach, society is right if man is placed in a position to be able to fully complete the personal definition of himself.

«The approach takes each persona s an end, asking not just about the total or average well-being but about the opportunities available to each person. It is focused on choice or freedom, holding that the crucial good societies should be promoting for their people is a set of opportunities, or substantial freedoms, which people then may or may not exercise in action: the choice is theirs» (Nussbaum 2011, p. 18).

The skills that this approach promotes are represented by «a set of (usually interrelated) opportunities to choose and to act» (Nussbaum 2011, p. 20) which are divided into ten «central capabilities» (Nussbaum 2018, p. 237) for a life fully and decently lived: life; physical health; physical integrity; senses, imagination, thought, feelings, practical reasoning; belonging; life with animals, plants, nature; play, control of one's environment.

«1. Life. Being able to live to the end of a human life of normal length; not dying prematurely, or before one's life is so reduced as to be not worth living

2. Bodily Health. Being able to have good health, including reproductive health; to be adequately nourished; to have adequate shelter

3. Bodily Integrity. Being able to move freely from place to place; to be secure against violent assault, including sexual assault and domestic violence; having opportunities for sexual satisfaction and for choice in matters of reproduction

4. Senses, Imagination and Thought. Being able to use the senses, to imagine, think and reason [...]

5. Emotions. Being able to have attachments to things and people outside ourselves; to love those who love and care for us, to grieve at their absence

6. Practical Reason. Being able to form a conception of the good and to engage in critical reflection about the planning of one's life

7. Affiliation. Being able o live with and toward others, to recognize and show concem for other human beings, to engage in various forms of social interaction; to be able to imaging the situation of another [...]

8. Other Species. Being able to live with concern for and in relation to animals, plants, and the world of nature

9. Play. Being able to laugh, to lay, to enjoy recreational activities

10. Control over One's Environment. [...] Being able to participate effectively in political choices that govem one's

life. [...] Being able to hold property [...] being able to work [...] and entering into meaningful relationships of mutual recognition with other workers ?

Fig1. The ten central capabilities (Nussbaum 2006, pp. 76-77): 
According to the capacity approach, no capacity is a priority and at the same time, no capacity can be left behind. If all are equally crucial, in Industry 4.0 one's being seems particularly at risk both in daily life and in research. This is the sixth capability referred to as «Practical Reason»: «being Able to form a conception of the good and to engage in critical reflection about the planning of one's life» (Nussbaum 2018, p. 237).

It is the capacity of «Practical Reason» that can assess each time the quality of research on the basis of its human measure. If the power of Industry is to increase the capabilities of man and to make him "perfect" thanks to the contributions of technology (bioengineering, biogenetics, artificial intelligence, ...), these increased capacities need to be evaluated and managed so that they are directed by man towards balanced development.

But until what point is the posthuman still human? If every humanism is born around the reaffirmation of the centrality of the human, it seems clear to us that this humanism will put at its centre an inhuman perfection. There is still a final question, however: these externally enhanced capabilities (from artificial intelligence, from bioengineering) how will they become capabilities related to the initiative of each human subject?" (Abbate 2019, p. 84, translation and italics ours).

The practical reason and the central capabilities can therefore represent the criteria on the basis of which it is possible to detect if and how the educational research is "of human measure" because through its objects, questions, methodologies, tools and practices - It is research that does not harm, but indeed promotes the development of these capacities. Only the existence of this human measure, constitutes the first element that can make educational research a quality research, if it is also a reliable and valid research.

The definition of human measure, in order to be able to effectively direct an educational research that is of quality in Industry 4.0, cannot be entrusted to spontaneous initiative and individual sensitivity. The definition of the human measure rather needs work that must be carried out starting from a specific training within the Phd programs and must be articulated on three different levels.

The first level is given by promoting awareness of the risks and the potentialities that nowadays research presents in the field of protecting and promoting human dignity. The second level is given by working at a constant inquiring of research questions, processes and findings so that they may never have the power of prejudicing human dignity. The third level therefore is given by increasing recognition and enhancement of that researches whose questions, processes and findings can really contribute to educate students, practitioners, policymakers and citizens so that they are in the best conditions to express themselves up to their full potential (OECD 2018, 2019) in order to participate with full dignity (Nussbaum 2011; Sen 2009) in an Industry 4.0 society.

\section{DECLARATIONS}

Funding: the research is not supported.

Conflicts of interest/Competing interests: the research has no conflicts of interest.

\section{REFERENCES}

[1] Abbate, F. (2019). CapacitAzione e Metamorfosi. In G. Alessandrini (Ed.), Sostenibilità e capability approach (pp. 77-88). Milano: Franco Angeli.

[2] Alessandrini, G. (2018). Critical Thinking e Key Competences dei millennials nel contesto Industry 4.0: nuove "sfide e responsabilità" della formazione universitaria. Professionalità Studi, 5 (I), 39-51.

[3] Bauman, Z. (1998). Globalization. The Human Consequences. Cambridge-Oxford: Polity Press-Blackwell Publisher.

[4] Bauman, Z. (2005). Intervista sull'identità. Roma-Bari: Laterza.

[5] Bennis, W. \& Nanus, B. (1985). Leaders: Strategies for Taking Charge. New York: Arper\&Row.

[6] Bertagna, G. (2017). Luci e ombre sul valore formativo del lavoro. Una prospettiva pedagogica. In Alessandrini, G. (Ed.), Atlante di Pedagogia del lavoro (pp. 49-89). Milano: Franco Angeli. 
[7] Bignardi, P., Marta, E. \& Alfieri, S. (2018), GENERAZIONE Z. Guardare il mondo con fiducia e speranza. Milano: Vita e Pensiero.

[8] Bill, G. (2017). VUCA 2.0: A Strategy for Steady Leadership in an Unsteady World. Forbes, https://www.forbes.com/sites/hbsworkingknowledge/2017/02/17/vuca-2-0-a-strategy-for-steadyleadership-in-an-unsteady-world/\#7e2c7e6c13d8. Accessed 18 April 2020.

[9] Bostrom, N. \& Roache, R. (2008). Ethical Issue In Human Enhancement. In Ryberg, J., Petersen, T. \& Wolf C., New Wavesin Applied Ethics (pp. 120-152). UK: Pelgrave Macmillan.

[10] Bostrom. N. (2005). Transhumanist Values. Review of Contemporary Philosophy, 4 (1-2), 87-101.

[11] Bostrom, N. \& Roache, R. (2008). Ethical Issue in Human Enhancement. In Ryberg, J., Petersen, T. \& Wolf, C., New Waves in Applied Ethics (pp. 120-52). UK: Pelgrave Macmillan.

[12] Bostrom, N. (2005). Transhumanist Values. Review of Contemporary Philosophy, 4, 87-101.

[13] CEGOS (2017). Millennials Insight: 2017 Survey Trends. http://static.cegos.it/wpcontent/uploads/2017/03/22170808/WhitePaper_millennials_insight_2017.pdf. Accessed 18 April 2020.

[14] Cipriani, A., Gramolati, A. \& Mari, G. (Eds.) (2018). Il lavoro 4.0. La quarta rivoluzione industriale e le trasformazioni delle attività lavorative. Firenze: Firenze University Press.

[15] Costa, M. (2017). Formatività e innovazione: un nuovo legame per industry 4.0. In Alessandrini, G. (Ed.), Atlante di Pedagogia del lavoro (pp. 219-236). Milano: Franco Angeli.

[16] Dewey, J. (1930). Individualism, Old and New. Balch: Minton.

[17] Ellerani, P. (2019). Tra "formale" e "informale": il Capability Approach come generatore di valore. In Alessandrini, G. (Ed.), Sostenibilità e capability approach (pp. 63-76). Milano: Franco Angeli.

[18] Garbellano, S. \& Meda, M. (2019). L'evoluzione delle soft skills nelle organizzazioni: una visione globale. In Pezzoli, M. (Ed.). Soft skills che generano valore. Le competenze trasversali per l'Industria 4.0 (pp. 1934). Milano: Franco Angeli.

[19] Gupta, D. \& Gupta, V. (2018). Effective Policing in a VUCA Environment: Lessons from a Dark Network. In Dhir, S. \& Sushil (Eds.). Flexible Strategies in VUCA Markets (pp. 89-111). Singapore: Springer.

[20] Howe, N. \& Strauss, W. (2000). Millenials Rising. The Next Great Generation. New York: Vintage Book.

[21] Iansiti, M. \& Lakhani, K.R. (2014). Digital ubiquity. How connections, sensors, and data are revolutionizing business. Harvard Business Review, XCII (11), 91-99.

[22] Marchesini, R. (2009). Il tramonto dell'uomo. La prospettiva post umanista. Bari: Dedalo.

[23] McAfee, A. \& Brynjolfsson, E. (2014). The second machine age. Work, progress, and prosperity in a time of brilliant technologies. New York-London: Norton.

[24] McAfee, A. \& Brynjolfsson, E. (2017). Machine, Platform, Crowd: Harnessing Our Digital Future. New York-London: Norton.

[25] Nussbaum, M.C. (2006). Frontiers of Justice. Disability, Nationality, Species Membership. CambridgeMassachusetts-London: The Belknap Press of Harvard University Press.

[26] Nussbaum, M.C. (2011). Creating Capabilities. The Human Development Approach. Cambridge-MA: Harvard University Press.

[27] Nussbaum, M.C. (2018). The Monarchy of Fear: A Philosopher Looks at Our Political Crisis. New York: Simon \& Schuster.

[28] OECD (2018). The future of education and skills. Education 2030. Paris: OECD.

[29] OECD (2019). OECD Future of education and skills 2030. Conceptual Learning Framework. Paris: OECD.

[30] Pew Research Center (2010). Millennials: A Portrait of Generation Next: Confident, Connected, Open to Change. org/wp-content/uploads/sites/3/2010/10/millennials-confident-connected-open-to-change.pdf. Accessed 09 January 2010.

[31] Seghezzi, F. \& Tiraboschi, M. (2018). Italy's Industry 4.0 Plan: An Analysis from a Labour Law Perspective. E-Journal of International and Comparative Labour Studies, 7 (1), 1-29.

[32] Sen, A. (2009). The Idea of Justice. London: Allen Lane.

[33] Whiteman, W.E. (1998). Training and Educating Army Officers for the 21 st Century: Implications for the United States Military Academy. Fort Belvoir-VA: Defense Technical Information Center.

[34] Whiteman, W.E. (1998). Training and Educating Army Officers for the 21 st Century: Implications for the United States Military Academy. Fort Belvoir-VA: Defense Technical Information Center.

[35] World Economic Forum (Ed.) (2016). The future of jobs. Employment, Skills and Workforce Strategy for 
Research's "Quality" in Industry 4.0. The Definition of a Human Measure for Evaluating of Research in Education

the Fourth Industrial Revolution. Genève: World Economic Forum.

[36] Zeilinger, A. (2003). Einstein Schleier. Die neue Welt der Quantenphysik. München: Beck ZIMA.

\section{AUTHOR's BIOGRAPHY}

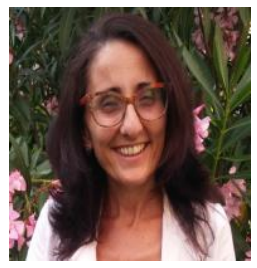

Emanuela Guarcello, is a Researcher in General Pedagogy. Her research interests are character education and character skills in primary school, judgment education with children and professionals in formal, non-formal and informal fields.

Citation: Emanuela Guarcello. "Research's "Quality" in Industry 4.0. The Definition of a Human Measure for Evaluating of Research in Education" International Journal of Humanities Social Sciences and Education (IJHSSE), vol 7, no. 11, 2020, pp. 113-119. doi: https://doi.org/10.20431/2349-0381.0711013.

Copyright: (C) 2020 Authors. This is an open-access article distributed under the terms of the Creative Commons Attribution License, which permits unrestricted use, distribution, and reproduction in any medium, provided the original author and source are credited. 